\title{
AN OUTSIDER'S INSIDE VIEW OF THE CHALLENGER INQUIRY
}

\author{
In the course of diagnosing the technical causes \\ of the Challenger space shuttle disaster, the author also formed \\ some impressions of NASA and became acquainted with some \\ of the pitfalls of participation in an official investigation.
}

\author{
Richard P. Feynman
}

A few days after the Challenger accident, on a Friday, I got a call from William Graham, who was the acting director of NASA. Mr. Graham had been a student of mine-at Caltech, and also at the Hughes Aircraft Company, where I gave a series of lectures-and thought maybe I would be of some use to the investigation. When I heard it would be in Washington, my immediate reaction was not to do it. I have a principle of not going anywhere near Washington or having anything to do with government.

So I called various friends like Al Hibbs and Dick Davies, trying to find an excuse why I shouldn't accept, but they all said I should. Then I spoke to my wife. "Look," I said. "Anybody could do it. They can get somebody else." "No," said Gweneth. And she explained how she thought I would make a unique contribution-in a way that I am modest enough not to describe. Nevertheless, I believed what she said. So I said, "OK. I'll accept."

So on Sunday, as I went to the telephone to call $\mathrm{Mr}$. Graham, I announced to Gweneth, "I'm going to commit suicide for six months. I won't be able to do any work with this physics problem I've been having fun with; I'm going to do nothing but work on the shuttle-for six months." I want you to understand my attitude at the time: I hadn't realized that it would take two years to get the shuttle flying again. I was going to try to work very hard so we

Richard P. Feynman is Tolman Professor of Physics at Calrech where he has taught since 1951 could get everything straightened out as quickly as possible.

The next day, Monday, I got a telephone call at $4 \mathrm{pm}$ : "Mr. Feynman, you have been accepted onto the commission"- which by that time was a "Presidential" commission, headed by former Secretary of State William P. Rogers. The first meeting would be in Washington, on Wednesday. So Tuesday, I asked Al Hibbs to get people at the Jet Propulsion Laboratory who knew something about the shuttle project to brief me on it right away. I want to say right now that I got nothing but wonderful cooperation from JPL, and that briefing was fantastic.

In order to prove how successful it was, I'll show you the first page of the notes I made in the briefing. (See the figure on the facing page.) You'll find that on the second line it says, "O-rings show scorching in clevis check." That means hot gas had burned through the O-rings on several occasions. Furthermore, they told me that the zinc chromate putty had bubbles, or holes. It turned out that yes, indeed, through those holes the gas came in to erode the O-rings. So already, on the second line of my briefing, I was told what was the matter with the shuttle.

The guys at JPL gave me a lot of other information. They told me about the engines, which are remarkable devices in the sense that the engineering involved is very good. They are way beyond normal. They are the most powerful engines for their weight that have ever been built. NASA was claiming that the engines were in the regular range of engineering, but they're not; the engines had many difficulties that the guys at JPL told me about. 


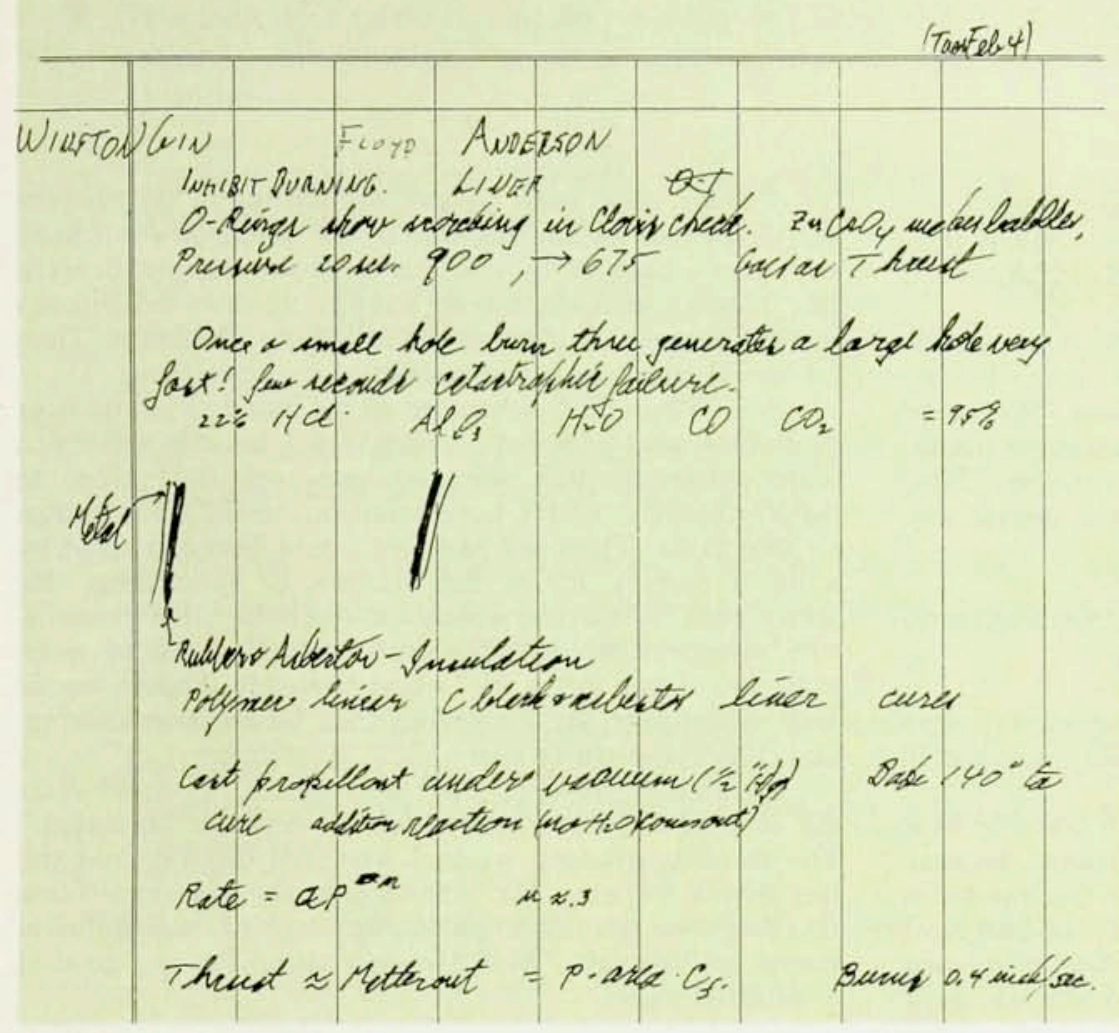

O-ring scorching already was recognized as a key to the Challenger disaster in Feynman's very first briefing. which rook place or the Jet Propulsion Laborarory on 4 February 1986. Shown here is the first page of his nores; the O-ring problem appears in the second line.

(I found out later that the people who worked on the engines always had their fingers crossed on each flight, and the moment they saw the shuttle explode, they were all sure it was the engines. But of course, the TV replay showed a flame coming out of one of the solid rocket boosters.)

Anyway, the point is that I got briefed. And this was done with lots of energy, just like the old days at Los Alamos, one guy after the other: first the rocket, then the engines and so forth. A guy would say, "We don't know about that; Lifer knows about that. Let's get Chuck Lifer in on this." So it was a very intensive briefing, the kind of thing I love, and I sucked up all the information like a sponge. I'm all set to go to Washington, and I go to Washington. (By the way, I took the "red-eye" across the country so I could stay here on Tuesday to learn about the shuttle. But the red-eye I never took again-you're so sleepy when you get there.)

I check into the Holiday Inn early Wednesday morning, I get into a taxi, and read the address of Mr. Rogers's office to the driver. We start off. Mr. Rogers's office was supposed to be near the hotel somewhere-the hotel was located near the Capitol and near everything big-but we go on and on, further and further, into worse and worse territory, until we finally find the address-by interpolation between two numbers. It was an empty lot there, with no number on it.

So now, what to do? I asked the taxi driver to go all the way back over this whole distance. (Meanwhile, my secretary tells me, she got a call from Washington:
"Where is he?") Then I noticed that my hotel was right across the street from NASA. Perfect. Right across the street. (In fact, it was also across a different street, on the other corner, from where the commission later had its offices.)

I thought, "What the hell, NASA's right across the street. I'll go to NASA. Somebody there must know where the meeting is." So I went into NASA, up to Mr. Graham's office, and somebody knew. They showed me the room. There, the room was full of people. There were television lights and everything, and all I could do was squash in the back and think, "How the hell am I gonna get to the front where I belong?" I worried about this for a while. Then I overheard a little bit about what they were saying, and it was evidently a different subject!

In the meantime, somebody from Mr. Graham's office had found the location of Mr. Rogers's office by phoning around and came down to get me. I finally made it to $\mathrm{Mr}$. Rogers's law offices a few blocks away, where I met the other commissioners. Over the course of the commission, we all became very good friends. We worked very hard together. This first meeting was the beginning of a very effective commission-with the exception of Mr. Chuck Yeager, who came to one meeting for about a half an hour and then absented himself from the commission in order to be free so he could make criticisms of it.

\section{First meetings}

Well, this first meeting was just a get-together. But Mr. Rogers did discuss the importance of our relationship to 
the press and how we have to be very careful with the press. "I know Washington," he kept saying. "We have to proceed in an orderly manner and be careful of leaks to the press."

The next meeting we had, on Thursday, was a public meeting - to start things off right with the press. By the way, we arrived at that meeting in limousines. We never got limousines again, but this time we arrived in limousines. I sat in the front seat. The driver says to me, "I understand a lot of very important, famous people are coming to this meeting...."

"Yeah, I s'pose.

"Well, I collect signatures," he says. "Could you do me a favor...

"Sure," I say.

I'm reaching for my pen when he continues, " ... and find Mr. Armstrong for me, so I can get his signature?" There are always greater people.

That meeting was a public briefing. A briefing in a public meeting is almost impossibly inefficient, because other people ask questions, and they're not the questions you want to ask, and you've got to sit through all that, and so on, and so on. It's very ineffective, and I began to learn how boring such things can be. The NASA officials were telling me only a small fraction of all the things I had learned at JPL two days before.

We had all come to the meeting in limousines, and when we came out, some of the limousines were still there. One of the commissioners was a general, General Kutyna, who looked very handsome and very impressive in his uniform. But what impressed me was his request: "Where is the nearest Metro station?" Right away I liked him, and I found out that my judgment in this case was excellent.

That night I wrote out for myself what kinds of questions I thought we should ask and all the things I wanted to study. I laid out the whole business, hoping to see what the rest of the commission wanted to do in our next meeting.

The next day, Friday, was more effective. General Kutyna told us in considerable detail what an accident investigation was like and how it was done, using the Titan missile as an example. I was very impressed with this. I was happy to learn that most of the questions I was going to ask were the kinds of questions one should ask, except that the investigation should be done in a much more methodical fashion than I had imagined.

At the end of this discourse, Mr. Rogers, who is not a technical man, said, "Yes, your investigation was a wonderful success, but we can't use those methods on our flight because we can't get as much information as you had on yours." That was patently false, because the shuttle, having people in it, was monitored much more carefully, so we had enormously more information than they had on the Titan. So there wasn't any doubt that we could do it.

In the meeting Mr. Rogers asked each of us how much time we could spend working on the commission. Many of the commissioners were retired, so they could spend 100 percent of their time. I also said I could spend 100 percent; I had everything arranged here at Caltech. (Nobody at Caltech ever said a word to me that I was shirking my work here, and I appreciate that.)
I tried very hard to get something to do. In the meeting I kept explaining that public briefings don't work with me; I have to talk to the technical people directly. $\mathrm{Mr}$. Rogers explained that we were going down to Kennedy Space Center in Florida on the following Thursday. Then we would start our investigation.

Next Thursday? I wanted to get going much quicker than that, and kept explaining that I could work much more efficiently if I went on my own and talked to people directly, and I kept mentioning different things I'd like to do. Then the meeting would be interrupted by a letter coming in for $\mathrm{Mr}$. Rogers, or something. $\mathrm{He}$ would read it-during which time various other commission members would whisper to me, "I'd like to work with you if you get a job"-and then Mr. Rogers would look up, apparently forgetting that I had been talking, and call on somebody else.

Finally, I would get the floor again. I would start my stuff again, and there would be another "accident." The meeting stopped while I was still talking, and the last words were by $\mathrm{Mr}$. Armstrong, the vice chairman. He said we wouldn't be doing any of the detailed investigative work. Well, the only thing I'm any good at is detailed work!

I was devastated. I was depressed and very uncomfortable. After the meeting I went up to Mr. Rogers. "Look," I said. "We've got nothing to do for five days!"

He said, "Well, what would you have done if you hadn't been on the commission?"

"I would have gone to Boston to consult for the Thinking Machines Company."

"Well, you go to Boston to consult, and come back in five days."

I couldn't take that. I was wound up like a spring, ready to go to work. I had intended to "commit suicide"do nothing else but work for the commission-for six months, and I had nothing to do. I was very depressed. I left that meeting feeling terrible.

\section{NASA briefing}

Soon I thought of something. I called up Mr. Graham, and said, "Listen, Bill, we're not doing anything for five days! I want to get started! I want to DO something!"

He says, "Sure! You could go to Johnson, where they take the telemetry; you could go to Marshall, where they make the engines; or you could go to Kennedy."

I didn't want to go to Kennedy, because it would look like I was trying to get information before the rest of the commission did. That was not what I was trying to do; I just wanted to get started. Sally Ride had said she wanted to work with me if I got something to do, and I knew she was at Johnson, so I said I'd go there.

So Graham says, "That's fine, you can do that. I know David Acheson, who's on the commission. He's a good friend of Rogers. I'll call him and see what he thinks." About half an hour later, Mr. Acheson calls me: "I think it's a great idea, but I can't convince Rogers. Rogers refuses to say why he's against it, and I just don't know why I can't convince him that you should get started."

Meanwhile, Mr. Graham thought of a compromise: He would bring people into NASA headquarters, there in Washington, to brief me the next day, on Saturday. But 


\section{Recommendations}

- The lack of a good secondary seal in the field joint is most critical and ways to reduce joint rotation should be incorporated as soon as possible to reduce criticality

- The flow conditions in the joint areas during ignition and motor operation need to be established through cold flow modeling to eliminate $\mathrm{O}$-ring erosion

- QM-5 static test should be used to qualify a second source of the only flight certified joint filler material (asbestos-filled vacuum putty) to protect the flight program schedule

- VLS-1 should use the only flight certified joint filler material (Randolph asbestos-filled vacuum putty) in all joints

- Additional hot and cold subscale tests need to be conducted to improve analytical modeling of $\mathrm{O}$-ring erosion problem and for establishing margins of safety for eroded $\mathrm{O}$-rings

- Analysis of existing data indicates that it is safe to continue flying existing design as long as all joints are leak checked with a 200 psig stabilization pressure, are free of contamination in the seal areas and meet $\mathrm{O}$-ring squeeze requirements

- Efforts needs to continue at an accelerated pace to eliminate SRM seal erosion

This NASA report with recommendarions on the shurtle was shown to Feynman during a NASA briefing. Feynman sensed a contradiction between the first and sixth points, which he underlined, as shown here.

Mr. Rogers called me up and said he didn't want me to do that. He kept explaining that we have to proceed in an orderly manner. I tried to explain how a technical person can talk to another technical person and get information very quickly, and that I wanted to DO something! I complained that we had had several meetings by now, but we hadn't yet discussed who was going to do what, or how to get started on the investigation.

Mr. Rogers said, "Well, do you want me to bother everybody and bring them together again for a meeting on Monday to discuss this?"

I said, "Yes!"

So he dropped the subject. Then he said, "I've heard you don't like your hotel. Let me put you in a good hotel."

I told him everything was fine with the hotel, and that I was perfectly satisfied with it. I just wanted to get to work! But he tried again, so I had to tell him, "Mr. Rogers, I am not interested in my personal comfort, only in the ability to do something!"

He said, "OK, go to NASA. It's OK." That's where our conversation ended.

So, I went. I got a private briefing all day at NASA on the engines and on the seals. The briefing on the seals was by $\mathrm{Mr}$. Weeks. It was a continuation of my JPL briefing, with many more details, including the history of these matters: how the problem had been discovered very early, how there had been "burn-throughs," "erosion," "blowbys" and what not, on flight after flight-how many there were, and how each flight readiness review had looked at the information and decided it was all right to fly.

At the end of this long report on the problem of the seals, there was a page with recommendations. This is how all information is communicated in NASA-by writing everything down behind little black circles, called "bullets." (See the figure above.)

When I looked at the recommendations, the thing that struck me was the contradiction between two of the bullets: The first one says, "The lack of a good secondary seal in the field joint is most critical. Ways to reduce the effects should be incorporated as soon as possible to reduce criticality." Then, further down the page, it says, "Analysis of existing data indicates that it is safe to continue flying with existing design..." -with some other conditions, such as using $200 \mathrm{lbs}$ of pressure in the leak test. (By the way, we discovered later that the leak test itself was causing the holes in the putty and was part of the reason for the failure of the seals!)

I pointed out this contradiction and said, "What analysis?" It was some kind of computer model. A computer model that determines the degree to which a piece of rubber will burn in a complex situation like thatis something I don't believe in!

I also found out that the matters that were causing trouble were brought up only at the "flight readiness review," where they were deciding whether to fly or not. There are so many considerations in deciding whether to fly, yet they brought up these critical matters only under those circumstances. In between the flights, there was no discussion of the problem-how it's going along or whether there's some progress.

So, what was really happening was that NASA had developed an attitude: If the seals leaked a little and the flight was successful, it meant that the seal situation wasn't serious. Therefore, the seals could leak and it would be all right-it was no worse than the time before.

Such an attitude is, of course, extremely dangerous. 
One or two out of five seals leaked-and only some of the time-so it's obviously a probabilistic matter, a thing you have no control over, an uncertainty. And it's not obvious that the next time you fly, the uncertainty won't click over a little bit more, statistically, and the seal will fail. Try playing Russian roulette that way: You pull the trigger and it doesn't go off, so it must be OK to do it again, right?

\section{Brittle rubber}

The next morning, Sunday, Mr. Graham took me with his family to the National Air and Space Museum. There we saw a moving picture about NASA, and it was so well done that I almost cried when I saw all the people involved at every level, how enthusiastic everybody was and how eager they were to make things work. That made me even more determined to help straighten things out as quickly as possible and to talk to the shuttle assembly people, the engineers and everybody else low enough down.

Later that day, General Kutyna called me up on the telephone. "I was working on my carburetor, and I was thinking. You're a professor," he says. "What, sir, is the effect of cold on the rubber seals?"

I caught on immediately to what he was thinking of. The temperature was $29^{\circ}$ when the shuttle flew, and the coldest previous launch was $53^{\circ}$. I said, "You know as well as I do. It gets stiff and loses its resiliency." That gave me a clue. Of course, that's all he had to tell me, and it was a clue for which I got a lot of credit later. But it was his idea. The professor of physics always has to be told what to look for. You just use your knowledge to answer the questions.

That weekend, The New York Times put out an article about a man named Cook, who was in the budget department of NASA. Mr. Cook had written a letter to his superior a year earlier, saying that the engineers knew there was something wrong with the seals, that they might have to fix the problem, and it might be expensive. $\mathrm{Mr}$. Cook was working out the budget and recommended that NASA prepare for the contingency that it would suddenly need a big load of money to fix this problem of the seals.

This gets into The New York Times, and so we have to have a special meeting. It's the press, you see; we have to match the press. So on Monday, everybody was called to a meeting anyway! But I remind you, we still hadn't had any meetings in which we did any work. At this emergency closed meeting, we got some interesting information: The NASA people who had been looking at the television pictures of the launch saw preliminary indications that there was smoke coming out of one of the joints just at liftoff.

More interesting still was a report by a man named MacDonald from the Morton Thiokol Company, who came to the meeting on his own. He said that the Thiokol Company engineers had noticed the low temperature, had been worrying about the seals, had known about the resilience not being there. Furthermore, they knew that when it is cold, the grease in the seals is very viscous so it can't move fast enough to close the gaps. The engineers were very, very worried about it just before the flight and reported to the people at Marshall that they should not fly below $53^{\circ}$ temperature, and that night it was $29^{\circ}$. But the engineers were told that that was an appalling decision, that they should think it over again, and they were given some apparently logical reason.

We later learned that in the discussions inside Thiokol, the engineers were still saying, "We shouldn't fly," but the managers made a decision nevertheless to go ahead and fly, and then they gave the usual, apparently logical reason, which was-never mind, I couldn't ever understand it. It's hopeless.

At any rate, that morning I had asked the question about how resilient the rubber is, and, as always, NASA was very cooperative at giving me information. That afternoon I got a stack of papers, the first page of which said, "Mr. Feynman of the commission wants to know about the resiliency of the O-ring rubber at low temperatures..."-and it's sent to the next subordinate. The subordinate writes to another subordinate, "Mr. Feynman of the Presidential commission wants to know ... " and so on, down the line. In the middle there's a paper with the answer, and then there's a series of papers-the submission papers-which explain that "this is in answer to your request at such-and-such a time."

So I get this stack of papers, just like a sandwich, and in the middle the answer is given to the wrong question! The answer I got was: when you squeeze the rubber for two hours at a certain temperature and pressure, what happens when you let go-how long it takes to creep back-over hours. And I was talking about fractions of a second during launch when the gap in the field joint is suddenly changing. So the information was of no use.

\section{Public experiment}

We were going to have a public meeting the next day. I was already getting tired of these public meetings and briefings because they were so time consuming and of so little use. I thought, "Now we're going to have an open meeting, and we're going to say exactly the same things that we did in the closed meeting." (It was a good idea: Mr. Rogers wanted to keep the public informed, so every time we discovered something, we would quickly have an open meeting to bring out the new material.) But I thought, "It's like an act: We have to hear the same things in the open meetings as in the closed meetings, and we won't learn anything new. And the information I got from NASA about the rubber is useless."

Later I'm feeling lousy and I'm eating dinner; I look at the table, and there's a glass of ice water. I think, "Damn it, $I$ can find out about that rubber without sending notes to NASA and getting back a stack of papers; all I've got to do is get a sample of the rubber, stick it in ice water and see how it responds when I squeeze it! That way, I can learn something new in a public meeting!"

I ask NASA for a piece of the rubber. It's impossible to get; they're very, very careful, and every piece of material is checked and counted and everything else, so you can't just go down to the stockroom and pick up a piece of rubber. But Mr. Graham remembered there were two pieces of the rubber in the field joint model NASA had shown us before and was going to use again in the open meeting. The two pieces of rubber were the real thing, about an inch and a half long each. We decided to meet in Mr. Graham's office the next morning before the meeting to see if I could take the model apart. (In the open meeting I would have to take the model apart quickly.)

The next morning I get up early. I come out of the hotel-it's snowing a little bit-and I'm dressed up in my suit because I'm going to the public meeting later. A taxi comes up, and I say to the driver, "I want to go to a hardware store."

He says. "A hardware store? There's no hardware 


\section{The O-Ring Problem and Thiokol's Attempted Solution}

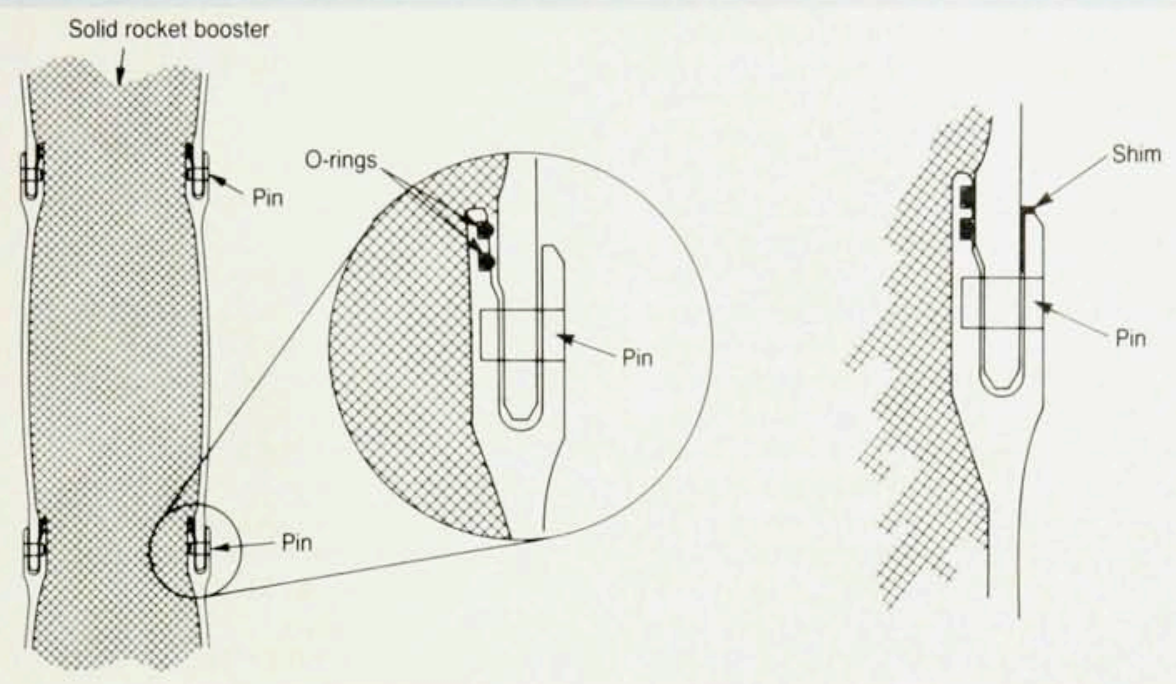

The cross section of the solid rocker booster (top left) shows the rubber $\mathrm{O}$-rings that encircle the rocker ar the joints. The $\mathrm{O}$-rings are approximately a quarter of an inch thick and lie on a circle $12 \mathrm{ft}$ in diameter-that's somerhing like $37 \mathrm{ft}$ around. When the booster originally was designed by the Morton Thiokol Company, it was expected that the pressure from the rocker would squash the O-rings so the joint would be securely sealed. What happened instead is, the joint is stronger than the wall (it's three times thicker) so thar under pressure the wall bows ourward, cousing the joint to open a little-enough to lift the rubber O-rings off the seal area.

Although the pieces of rubber are called $O$-rings, they re nor used the woy $O$-rings are normally used. In ordinary circumstances, such as for sealing oil in the moror of an automobile, while there are sliding parts and rorating shafts, the gaps are always the same. An O-ring just sits there in a fixed position. Bur in the case of the shurtle, the gop expands as the pressure builds up in the rocket. And to maintain the seal, the rubber has to expand fast enough to close the gap-in fractions of a second. Thus the resilience of the rubber became a very essential part of the design. When the Thiokol engineers were discovering these problems, they went ro the Parker Seal Company, which manufactures the rubber, to ask for advice. The Parker Seal Company rold Thiokol that O-rings were not meant to be used that way, and so they could give no advice.

Alrhough it was known from nearly the beginning that the joint was nor working as it was designed to. Thiokol kept struggling with the device. They made a number of makeshift improvements. One was to pur shims in to keep the joint tight (rop right). Ar first they thought they would adjust each shim to the right thickness as they went around (the rocket would become slightly out of round after each use), but that was expensive, so they made all the shims the same thickness. Of course, it wasn't enough. The joint still leaked, and they were thinking how to fix it, and the shurtle kept flying. That is one of the things you have ro understand: The program kepr going. no marter what

stores here. The Capitol is just up the street-we're in downtown Washington!" Then he remembered where he had seen a hardware store once, some distance away, and we went there. It didn't open till 8:30 - it was about 8:15so I waited outside, in my suit coat and tie, a costume I had assumed since I came to Washington in order to move among the natives without being too conspicuous.

The suit coats that the natives wear inside their buildings (which are well heated) are sufficient for walking from one building to another, or from a building to a taxi, if the distances are too great. (All the taxis are heated.) But I observed that the natives seem to have a strange fear of the cold: On top of their suit coats they put on overcoats if they wish to step outside. I hadn't bought an overcoat yet, so I was still rather conspicuous standing outside the hardware store in the snow.

When the hardware store opened, I bought myself some screwdrivers, pliers, clamps and so on, because I wasn't sure exactly what I would need.

When I got to NASA I began thinking the clamps were too big to put into a glass. So to get some small clamps I went to the medical department of NASA, where I had gone several times before (my cardiologist was trying to take care of me by telephone). I went up to Graham's office. He was very cooperative, as always, and we saw that I could open the model very easily with just a pair of pliers. So there was the rubber, right in my hand, and al- though I knew it would be more dramatic and honest to do the experiment directly in the meeting, I cheated-I couldn't resist. I tried it. And, after all, it would be quite a flop it if didn't work! So, following the example of having a closed meeting before an open meeting I must tell you I discovered it worked before I did it in the open meeting.

I kept wanting to do my experiment all during the meeting, but General Kutyna, who was sitting next to me, gave me advice. He had given me advice before. At the first public meeting he had leaned over and said, "Copilot to pilot: Comb your hair." So now he was saying, "Copilot to pilot: Not now!"

So when he told me, "Now!" I did it, and everything went all right. As you probably know, I demonstrated that the rubber had no resilience whatever when you squeezed it at that temperature, and that it was very likely a partial cause of the accident. We all agreed later that that, in fact, was true.

On Wednesday, 12 February, we had no meeting, so I wrote a letter home. I told my wife she was right, that in certain ways I was unique. One of the ways I was unique was that I was not connected to any organization-I had no weakness from that point of view. I was, of course, connected with Caltech, but that's not a weakness! For example, General Kutyna was in the Air Force, so he couldn't say everything exactly the way he wanted, because he might get in trouble with the Air Force. Sally 
Ride still had a job at NASA. Everyone on the commission had some kind of connection and therefore some kind of weakness, but I was apparently invincible.

But General Kutyna warned me that when they fly airplanes, they have a rule: Check six. Most airplanes are shot down this way: A guy is flying along, looking in all directions, and feeling very safe. An airplane flies up behind him (at "six o'clock"; "twelve o'clock" is directly in front), and he gets hit. So you always have to check six o'clock. So I began to write, "Check six!" on every note paper I had and developed a kind of paranoia.

For example, I have a cousin who previously had been with the Associated Press as White House correspondent and is now with CNN; I also have a nephew who works for The Washington Post. When I had some time I would visit with them - eating dinner, and so on. It was very pleasant, but we made sure we never said a word about anything I was doing, because I didn't want to be responsible for any leaks. I told $\mathrm{Mr}$. Rogers that I had these associations with the press. He smiled and said, "It's perfectly all right. I used to work for so-and-so"-he had some connection with the press too. He just laughed; there was no problem. But my paranoia had developed to such a point that I thought, "That was too easy; he's going to get me that way!" So I stopped seeing my cousin. That was stupid: There were no problems; it was just my state of mind.

I did, however, keep talking to the press-openly, always giving my name. I didn't want any hocus-pocus about "unidentified sources," or anything. My cousin had taught me that the press is not something to be afraid of, and it turns out to be true. I found that out several times. The first time was when The New York Times put out an article after I did the ice water experiment; during the public meeting I had no time to explain what its meaning and importance were, but they had it all explained perfectly.

Another time, NBC interviewed me-they caught me in the lobby of my hotel. They interviewed me for 15 to 20 minutes - the lady reporter was very short and very niceand I talked in my usual, careful, professional way, with all the caveats and so forths and so ons. I saw the interview later on the "Nightly News": I was on for about two seconds-I say something, and BOOM!-it's over. But it was good: The report carried the line of what I said, and the reporter put the context around it, saying things like, "The professor went on to say that this was only the result of a mathematical model and might be uncertain"-stuff like that. It was excellent. It was very short, carefully put together and excellent-except for one thing: Because I'm not experienced, I didn't look into the camera when I spoke. Instead, it looked like I was talking to my dog.

\section{Visit to Kennedy}

Well, finally, on Thursday, we get to Kennedy. The main briefing turned out to be the way I thought it would bewe didn't get any useful information just looking around at the "gee-whiz" place. But before that, we had two meetings in which we got a lot of information. We got a detailed look at the pictures of the smoke, which made it very apparent that the leak of gases through the seal had started immediately after ignition, then somehow plugged itself up temporarily, and finally ended up with a flame coming through. We also got all the details on the Thiokol-Marshall discussions, in which the engineers never changed their minds; only the manager did, under pressure from Marshall.

After two days at Kennedy, we were supposed to return to Washington. I thought, "Now, at last, here I am. Now I've got a chance to talk to everybody."
I told Mr. Rogers I wanted to stay at Kennedy, and he said, "I'd prefer that you didn't stay down here, but of course you can do whatever you want."

I said, "Well, OK, then, I'll stay."

So I stayed at Kennedy a few more days. I ran around and found out more about the pictures from the photograph guys; I found out about the ice that had been on the launch pad from the ice crew. They told me they had gotten some funny numbers for the temperature on the morning of the launch, and we discussed what was wrong. We called up the people who made the instrument, and tried to find out how the instrument was built so we could understand the errors, but they suddenly clammed up, obviously afraid that they were going to be blamed for the shuttle disaster.

I explained to the manufacturer that the instruments were not used in accordance with their manual (they had been used too soon after being taken out of the box), and we wanted to know what the effect of that misuse would be on the apparent temperature readings, and so forth. I finally got them to explain it all. They said our errors were reproducible. So we set up an experiment in which we reproduced the circumstances, and we corrected the temperature readings. I'm only trying to say I was working hard.

Another thing came up while I was running around down there at Kennedy. I had predicted that Mr. Rogers was going to try to fix me by overloading me-by giving me a lot of stuff to do. Sure enough, it happened; the commission staff in Washington kept sending me things to do. But as the instructions came in, I had done them already - they didn't realize how fast I am at getting information and understanding it and going on to the next thing.

The only thing they sent me that I didn't do had to do with a certain memo whose existence they had discovered. During the assembly of the solid rocket boosters, someone had written cavalierly, "Let's go for it!" The staff didn't like the attitude on the part of the workers, and they wanted to find that piece of paper. By that time I knew how much paper there was in NASA so I was sure it was a trick to make me get lost and to do nothing. So I did nothing about it.

\section{Meeting with workers}

I talked to Mr. Lamberth, who was in charge of the assembly of the SRBs. He told me about the problems he had with the workmen. They had a little accident earlier, and he had to discipline them about it, and then he told me about another incident: The SRBs become a little bit out of round after each use. When the workers were trying to make the rocket round again with the rounding machine-a rod with a hydraulic press on one end and a nut on the other-they were only supposed to go up to $1250 \mathrm{lbs}$, according to the manual. But they couldn't get it squashed enough that way, so they took a wrench and tightened the nut on the other end of the rod to squeeze it some more. That made the rocket round, all right, but one of the workmen noticed that the pressure had gone up to 1350 lbs that way. Well, a gauge measures the force applied to a rod from either end, so tightening the nut increases the pressure past $1250 \mathrm{lbs}$, of course! So Mr. Lamberth admonished the workers to follow the manual. He said the workers weren't like they used to be, and he was very disturbed.

So I go down and talk to the workers. First of all, I'm surprised to find that the foreman doesn't know anything about this admonishment. He knew about the $1350 \mathrm{lbs}$, but he didn't know he had been admonished. He said, "No, we weren't admonished; we were following the procedures 


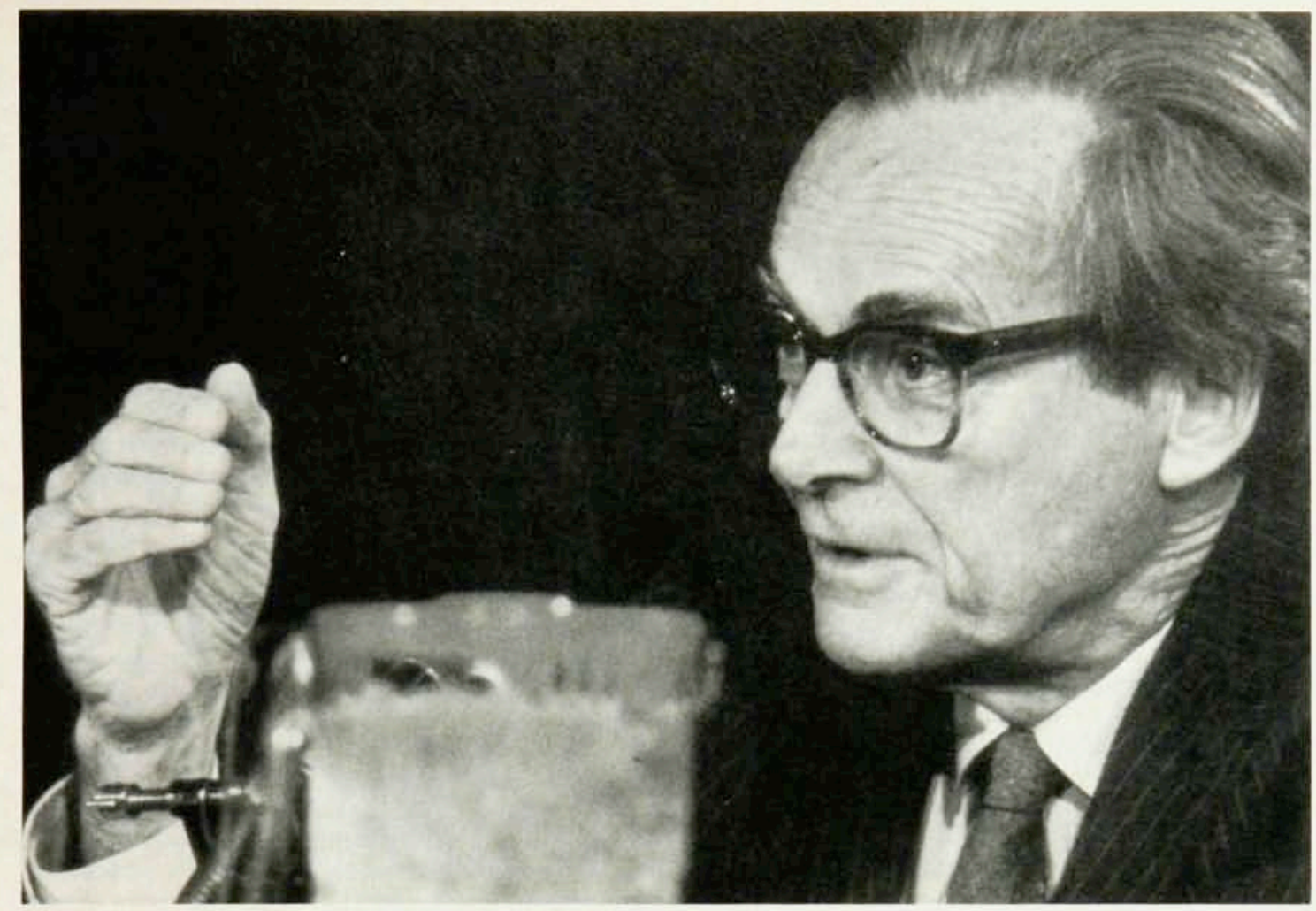

Feynman demonstrates effect of cold on rubber ar a public meering of the Presidential commission on 11 February 1986 by dipping pieces of rubber-the same kind the O-rings are made of-in a pitcher of ice water.

in the manual." Sure enough, the manual said to tighten the nut after the pressure reaches $1250 \mathrm{lbs}$-it said so in black and white! It didn't say that tightening the nut would increase the pressure; the people who wrote the manual probably weren't quite aware of that. So the workmen had, in fact, followed the manual perfectly. (I later found out that as a result, the manual was revised to allow for higher pressure, and that only the hydraulic jack was to be used to increase the pressure. The step about tightening the nut was eliminated.

So Mr. Lamberth really didn't know what happened underneath. He said he had admonished the workmen, but he never talked to them directly. So he had the idea that his workmen were no longer like they used to be, but I tell you, they really were. They had a lot of information but no way to communicate it. The workmen knew a lot. They had noticed all kinds of problems and had all kinds of ideas on how to fix them, but no one had paid much attention to them. The reason was: Any observations had to be reported in writing, and a lot of these guys didn't know how to write good memos. But they had good knowledge, they worked very hard and they were very enthusiastic.

While I was doing my work down at Kennedy, Mr. Rogers was in Washington appearing before a Congressional committee. (Congress was considering whether to set up its own investigation of the accident.) Senator Hollings said, "So who have ya got, there, on your commission? Ya got a couple of astronauts, a Nobel prizewinner, a general, some businessman and a couple of lawyers. What you really need is gumshoes, who will be right down there at Kennedy, eating lunch with the very guys who do the work on the shuttle."

And Mr. Rogers was able to reply, "You'll be interested to know, Senator, that the Nobel prizewinner is down there at Kennedy, right now, doing exactly that!"
(Although Mr. Rogers couldn't have known it, I was actually eating lunch with some of the engineers at exactly that time.) So $\mathrm{Mr}$. Rogers gradually realized I wasn't quite so useless. We got to respect each other very much-I think he ultimately respected me, and I certainly do respect him for his abilities.

I went back to Washington, and I got into more and more difficulties. The next meeting we had was a public meeting, and I was questioning $\mathrm{Mr}$. Lund of the Thiokol Company, who had changed his mind about launching the shuttle. Somebody at Marshall had told him to put on his "management hat" instead of his "engineering hat," and so he changed his opinion. I was asking him, "Don't you understand the principles of probability?" when suddenly I had this feeling of the Inquisition.

Mr. Rogers had pointed out to us that we ought to be careful with these people, whose careers depended on us. $\mathrm{He}$ said, "We have all the advantages. We're sitting up here, they're sitting down there; they have to answer our questions, we don't have to anwer their questions. It isn't fair." Suddenly all this came back to me and I felt terrible. I couldn't do it the next day, so I went back to California, just for a day or two, to rest up.

While I was in Pasadena, I went over to JPL and discussed the enhancement of the pictures with Jerry Solomon and Meemong Lee; they were studying the flame that had appeared on the side of the SRB just before the main fuel tank exploded. I had just been in Washington, hearing the NASA managers talk through a fog. What a difference-just like with the photograph guys and the ice crew at Kennedy, everything was so direct and simple at Caltech and JPL. What a difference!

\section{Communication problem}

We finally divided into working groups, and I went to Marshall with General Kutyna's group. The first thing 
that happened there was, a range safety officer by the name of Ulian came to tell us about a discussion he had had with NASA higher-ups about safety. Mr. Ulian had to decide whether to put explosive charges on the side so ground control could destroy the shuttle in case it was falling onto a city. The big cheeses at NASA said, "Don't put any explosives on, because the shuttle is so safe. It'll never fall onto a city."

$\mathrm{Mr}$. Ulian tried to argue that there was danger. One out of every 25 rockets had failed previously, so Mr. Ulian estimated the probability of danger to be about 1 in 100 enough to jusify the explosive charges. But the higher-ups at NASA said that the probability of failure was 1 in 100000 . That means if you flew the shuttle every day, the average time before your first accident would be 300 years - every day, one flight, for 300 years-which is obviously crazy! Mr. Ulian also told us about the problems he had with the big cheeses-how they didn't come to the meetings sometimes and all kinds of other details.

Then I thought of this question: By now we had found out that the flight failed because one of the seals had broken, and the higher-ups had told us they didn't know anything about the seals problem-even though I was able to find out about it right away at JPL, before I even went to Washington. We saw that NASA had no system for fixing the problem, even though engineers were writing letters like, "HELP!" and "This is a RED ALERT!" Nothing was happening. My question was: Does this lack of communication between engineers and management also exist in other places? I thought, "I oughta find out whether this is a characteristic of the whole system, or whether it's true just for Morton Thiokol, and we happened to find out about it because the O-rings busted." So I told the people at Marshall I wanted to find out about the engines. I wanted to talk to a couple of engineers without any managers around.

"Yes, sir, we'll fix it up. How about tomorrow morning at 9:00?"

The next day I come in, and there's engineers, all right, but there's also managers, and a great, big book: Presentation Made on February Such-and-Such to Commissioner Richard P. Feynman-all prepared during the night.

"Geez! It's so much work!" I said.

"No, it's not so much work; we just put the regular papers in that we use all the time."

The engine is extremely complex and hard to understand, and the engineers were explaining to me how it worked, showing slide after slide. I asked my usual dumbsounding questions.

After a while, Mr. Lovingood, a middle manager there, said, "Mr. Feynman, we've been going for two hours now. There are 123 pages, and we've only covered 20 ."

"It's all right, don't worry," I said. "I'm confident that it'll go faster as we go along, but I want my questions answered at the beginning. Otherwise, I can't understand it."

Suddenly I got an idea. I said, "All right, I'll tell you what. In order to save time, the main question I want to know is this: Is there the same understanding, or difference of understanding, between the engineers and the management associated with the engines as we have discovered associated with the solid rocket boosters?"

Mr. Lovingood says, "No, of course not. Although I'm now a manager, I was trained as an engineer."

I gave each person a piece of paper. I said, "Now, each of you please write down what you think the probability of failure for a flight is, due to a failure in the engines."

I got four answers - three from the engineers and one from Mr. Lovingood, the manager. The answers from the engineers all said, in one form or another (the usual way engineers write- "reliability limit," or "confidence sub so-on"), almost exactly the same thing: 1 in about 200. Mr. Lovingood's answer said, "Cannot quantify. Reliability is determined by studies of this, checks on that, experience here"-blah, blah, blah, blah, blah.

"Well," I said, "I've got four answers. One of them weaseled." I turned to Mr. Lovingood and said, "I think you weaseled."

He says, "I don't think I weaseled."

"Well, look," I said. "You didn't tell me what your confidence was; you told me how you determined it. What I want to know is: After you determined it, what was it?"

He says, "100 percent." The engineers' jaws drop. My jaw drops. I look at him, everybody looks at him-and he says, "Uh ... uh, minus epsilon?"

"OK. Now the only problem left is, what is epsilon?"

He says, "1 in 100000 ." So I showed Mr. Lovingood the other answers and said, "I see there is a difference between engineers and management in their information and knowledge here, just as there was in the case of the rocket, but let me not bother you about it; let's continue with the engine."

So they continued telling me about the engine, and soon I understood how it worked. Then they told me about all the problems they had had with it-blades cracking, and all kinds of other difficulties. And I discovered the same game, just as in the case of the solid rocket boosters, of reducing criteria and accepting more and more errors that weren't designed into the device.

Later I also checked the avionics, the software NASA uses on its computers for controlling the shuttle from launch to landing, to find out if a similar situation existed there. But in this case, on the contrary, everything was very good; the engineers and the managers communicated well with each other, and they were all very careful not to change their criteria of acceptance during flight reviews. I found the avionics completely satisfactory.

\section{Writing report}

I wrote up what I found out about these things into a special report, hoping that the other members would see it for discussion. I sent it to $\mathrm{Al} \mathrm{Keel,} \mathrm{the} \mathrm{executive} \mathrm{officer}$ whom Mr. Rogers had selected to coordinate everything on the commission. He told me on the telephone that he had received it and that he would show it to everybody.

By this time we were beginning to write up our part of the main report about the accident. General Kutyna had set up a whole system at Marshall for doing so. It lasted about two days before we got a message from Mr. Rogers: "Come back to Washington. You shouldn't do the writing down there." So we went back to Washington, and Mr. Graham lent me an office and a secretary who was very, very good. I helped our group write up its part of the main report-with a lot of input from $\mathrm{Mr}$. Keel.

All this time I had expected that we would be meeting in Washington to discuss what we had found out so far, to think it out together and look at it from different perspectives-in addition to the astronauts there were lawyers and industralists, there were scientists and engineers, and so on-and to discuss with each other where to go next. But in our meetings, all we ever did was what they called "wordsmithing"-correcting punctuation, refining phrases and so on. We never had a real discussion of ideas!

Besides the wordsmithing, we discussed the typography and the color of the cover. At each meeting we were asked to vote, so I thought it would be efficient to vote for the same color we had decided on in the meeting before-but it turned out I was always in the minority! 
appropriate and said so. We argued back and forth a little bit, but then I had to catch a plane to New York, where I was going for the weekend. While I was in the airplane, I thought about it some more, and the more I thought about it, the more I thought what a mistake it looks like-just like one of the NASA reports, like the one I had seen back at the beginning, with the contradictory bullets: There's all these troubles, but in the end we recommend to keep on flying!

I knew I didn't like it. Furthermore, we hadn't discussed it at a meeting! It was just Mr. Rogers's idea. I didn't want to call up Mr. Rogers and argue with him on the telephone, so I quietly and thoughtfully wrote out a letter to him, carefully explaining why I didn't like the tenth recommendation. To make sure it got there right away, I dictated my letter over the telephone to Mr. Rogers's secretary, who typed it up and handed it to him right in his office!

When I came back from New York, Mr. Rogers told me that he had read my letter. He said he agreed with it, but that I was outvoted.

I said, "How was I outvoted, when there was no meeting?" I thought my ideas about this were worth discussing with the other commissioners, and I wanted to know what they thought about my arguments.

"I know, but I called each one of them up," he said, "and they've all agreed. They've all voted for it."

So I said, "Well, I'd like a copy of this recommendation," and I went off to make a copy of it. When I came back, Mr. Keel said he forgot that they hadn't talked to Mr. Hotz-Mr. Hotz was there, you see, so I could ask him right away. They forgot that they hadn't talked to Mr. Hotz. I went to lunch with $\mathrm{Mr}$. Acheson and Mr. Hotz, and it seemed like Mr. Hotz agreed with me. When we went back to Mr. Rogers's office, Mr. Acheson explained to me, "It's only 'motherhood and apple pie.' If this were a commission for the National Academy of Sciences, your objections would be proper. But since this is a Presidential commission, we should say something for the President."

"I don't understand the difference," I said. (Being naive at the right time is often a good idea.) "I just don't understand. Why can't I be careful and scientific when I'm writing a report to the President?" (Being naive doesn't always work: My argument had no effect.)

I was very concerned by all this, and I came home for a while, very disturbed. I then got the idea-which I hadn't had before-to call up some of the other commissioners. I'll call them A, B and C.

I call A. He says, "What tenth recommendation?"

I call B. He says, "Tenth recommendation? What are you talking about?"

I call C. He says, "Don't you remember, you dope? I was in the office when Rogers first told us, and I don't see anything wrong with it."

Although some of the commissioners agreed with the tenth recommendation, I still thought we should have discussed it in a meeting. I had also been railroaded into modifying my report, even though it was going to appear only as an appendix. I talked to my sister, who used to work in Washington.

She said, "Well, if they do that to your report, what happens to all the work you did on the commission? Your contribution wouldn't be seen. It would appear as if you didn't do anything."

I said, "Aha!" and I sent a telegram to Mr. Rogers: PLEASE TAKE MY SIGNATURE OFF THE FRONT PAGE OF THE REPORT UNLESS TWO THINGS OCCUR: 1) THERE IS NO TENTH RECOMMENDATION, AND 2) MY REPORT APPEARS AS AN APPENDIX WITHOUT MODIFICATION FROM VERSION \#23 OF MR. HANSEN.
I knew by this time I had to define everything carefully! (By the way, everything had 23 versions. It has been noted that computers, which are supposed to increase the speed at which we do things, have not increased the speed at which we write reports. We used to make only three versions-because they're so hard to type-and now we make 23 versions!)

The result of this telegram was that Mr. Rogers and Mr. Keel tried to compromise. They asked General Kutyna to be the intermediary, because they knew he was a friend of mine. What a good friend of mine he was, they didn't know.

The general calls me up, and right away he says, "Hello, professor! Let me first tell you, I'm with you. But I've been given the job of convincing you to change your mind, and I have to give you all the arguments."

"Fear not!" I said. "I'm not gonna change my mind. Just give me the arguments, and fear not."

So he gave me all the arguments, none of which had any effect. The arguments were all kinds of crazy things. For example, "If you don't accept the tenth recommendation, they're not going to accept the compromise they already made about putting your report in as an appendix." I didn't worry about that one, because I didn't have to sign the main report, and I could always put out my report by myself.

Another argument was that they noticed I was always talking to the press and they would claim I was doing this as a publicity stunt to sell more copies of my book. That one made me smile, because I could imagine the laughter it would produce from my friends at home. I knew that nobody I cared about would believe it.

But finally, I did compromise. I said, "Instead of making it a recommendation, just make it a concluding thought and change the wording from 'strongly recommends' to simply 'urges.',

They accepted that.

A little bit later, Mr. Keel calls me up: "Can we say 'strongly urges'?"

I said, "No. Just 'urges.',

\section{Meeting with press}

So I put my name on the main report, my report got in as an appendix, and everything was all right. We gave our report to the President on a Thursday in a ceremony at the White House in the Rose Garden. The report was not to be publicized until Monday, so the President could study it.

During those three days the newspaper reporters were working like demons. They knew the report was finished, and they were trying to scoop each other to find out what was in it. They kept calling me up because I had been so cooperative before. I told my secretary to say that I had no comment on anything; I would answer all their questions on Tuesday at my news conference.

Well, I didn't know it, but someone had leaked that this argument had gone on. The only man who knew about it, I think, was Mr. Hotz. He may have thought it would help me in pushing my point, but for whatever reason, it leaked. Some paper in Miami started it, and soon the story was running all over about this argument between me and Mr. Rogers. So when the reporters called me up, they'd get the message, "He has nothing to say; he'll answer all your questions at his press conference on Tuesday."

That sounded very suspicious, so my press conferece turned out to be very popular. That's what most of the questions at the news conference were about. So I found myself repeating that I don't have any problem with $\mathrm{Mr}$. Rogers.

My reaction is that I like him, and that he's a 


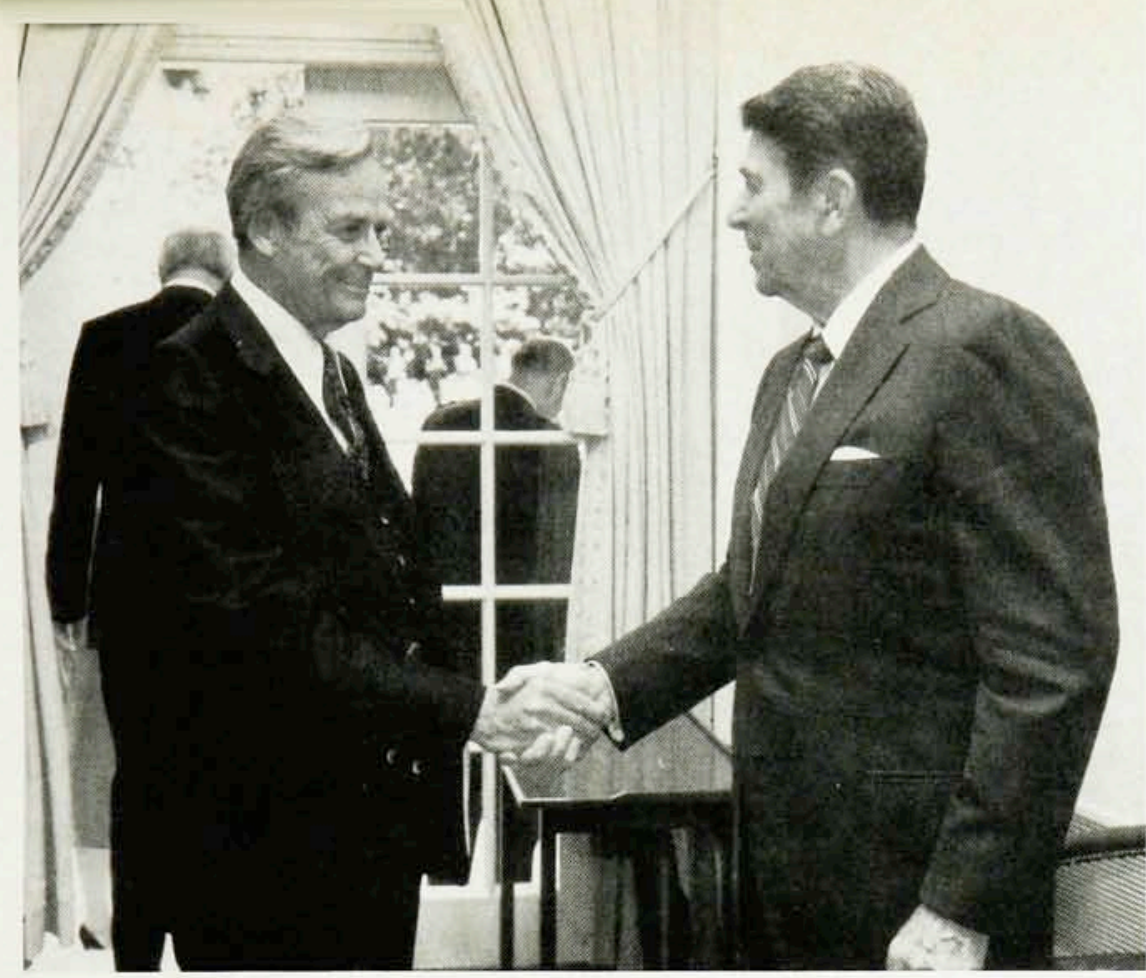

The President and Feynman shake hands the day the Presidential commission formally presents its report at the Whire House

genuinely fine fellow. But I reserve in my head the possibility-not as a suspicion, but as an unknown-that I like him because he's such a good politician that he knew how to make me like him. I prefer to assume he is the way he appears. But as a scientist, I'm not sure that my evidence is complete. And I was in Washington long enough to know that I can't tell.

\section{Summing up}

Finally, I would like to say something about the general deterioration of NASA - and the fact that there was no information coming up from the engineers to the management. Just the other day I was reading a book by Harvey Brooks in which he talked about innovation. $\mathrm{He}$ explained that innovation doesn't have to be the direct invention of a machine; an innovation could be the way things are made, such as the Ford mass production line or, as in another of his examples, the management system developed at NASA for the Apollo program, which involved the cooperation of so many contractors and subcontractors. The system they evolved was an innovation, a great development. This was more than 20 years ago. But in the meantime, something happened that happens to many human innovations-it deteriorated. The question is: How and why? I don't know.

I invented a theory, which I have discussed with a considerable number of people, and many people have explained to me why my theory is wrong. But I don't remember their explanations as to why it's wrong-you never can, because that's the way you're built! I am a weak human, too, so I cannot resist telling you what I think is the problem.

When NASA was trying to go to the Moon, it was a goal that everyone was eager to achieve. Everybody was cooperating, much like the efforts to build the first atomic bomb at Los Alamos. There was no problem between the management and the other people, because they were all trying to do the same thing. But then, after going to the Moon, NASA had all these people together, all these institutions and so on. You don't want to fire people and send them out in the street when you're done. So the problem is what to do.

You have to convince Congress that there exists a project this organization can do. In order to do so, it is necessary (at least it was apparently necessary in this case) to exaggerate - to exaggerate how economical the shuttle was going to be, to exaggerate the big scientific facts that would be discovered. (In every newspaper article about the shuttle there was a statement about the useful zerogravity experiments-such as making pharmaceuticals, new alloys and so on-on board, but I've never seen in any science article any results of anything that have ever come out of any of those science experiments which were so important!) So NASA exaggerated how little the shuttle would cost, they exaggerated how often it could fly, to such a pitch that it was obviously incorrect-obvious enough that all kinds of organizations were writing reports, trying to get the Congress to wake up to the fact that NASA's claims weren't true.

I believe that what happened was-remember, this is only a theory, because I tell you, people don't agree-that although the engineers down in the works knew NASA's claims were impossible, and the guys at the top knew that somehow they had exaggerated, the guys at the top didn't want to hear that they had exaggerated. They didn't want to hear about the difficulties of the engineers-the fact that the shuttle can't fly so often, the fact that it might not work and so on. It's better if they don't hear it, so they can be much more "honest" when they're trying to get Congress to OK their projects.

So my theory is that the loss of common interestbetween the engineers and scientists on the one hand and management on the other-is the cause of the deterioration in cooperation, which, as you've seen, produced a calamity.

A slightly different version of this article, edited by Ralph Leighton, appeared in the Fall 1987 issue of Caltech's Engineering and Science magazine. The article is reprinted here by permission of the Caltech Alumni Association. 